\title{
EMISSION ANALYSIS ON THE INFLUENCE OF FERROFLUID ON RICE BRAN BIODIESEL
}

\author{
YUVARAJAN DEVARAJAN ${ }^{\text {\# }}$ AND VENKATA RAMANAN MADHAVAN ${ }^{2}$
}

${ }^{I}$ School of Mechanical and Construction, Veltech Dr. RR \& Dr. SR University, Chennai, India

${ }^{2}$ Institute for Energy Studies, Department of Mechanical Engineering Anna University, Chennai, India

\begin{abstract}
Increase in $\mathrm{NO}_{\mathrm{x}}$ emission is one of the important drawbacks for using biodiesel as an alternative for petroleum diesel. Several studies had been carried out to reduce the NO emissions level in biodiesel. The present work is the result of an attempt wherein ferrofluid is added to rice bran oil methyl ester in the way of analyzing its effects on emission characteristics. Magnetite concentrate is exothermic and is known for its characteristics of releasing copious heat at higher temperatures. Nanofluid using magnetite was synthesized by reacting Iron II $\left(\mathrm{FeCl}_{2}\right)$ and Iron III ( $\mathrm{FeCl}_{3}$ ) in an aqueous ammonia solution to form Magnetite $\mathrm{Fe}_{3} \mathrm{O}_{4}$ (Ferro fluid). Release of heat by magnetite during the combustion process would counterbalance the conventional limitations related with biodiesel such as increased delay period, inferior combustion rate and higher NOx emissions etc. Experiments were conducted with Rice Bran Oil Methyl Ester (RBOME) and Rice Bran Oil Methyl Ester with addition of ferrofluid (RBOMEF) and are compared with petroleum diesel. RBOMEF was prepared comprising $97.7 \%$ biodiesel, $2 \%$ magnetite based ferrofluid and $0.3 \%$ surfactant by volume was used in a Compression Ignition engine. The experimental analysis found a decrease in $\mathrm{HC}$, $\mathrm{CO}$ and NOx emissions of $10.8 \%, 9.1 \%$ and $8.49 \%$ respectively.
\end{abstract}

Key words: Ferrofluid, Nanofluid, Rice bran oil, Emissions.

\section{INTRODUCTION}

Biodiesel is a promising alternative fuel over diesel as it emits lesser quantity of carbon monoxide, hydrocarbon and particulate matter. Conversely, Biodiesel fuelled engine also emits significant measure of nitric oxide $\left(\mathrm{NO}_{\mathrm{x}}\right)$ emission when compared with petroleum diesel [1 \&2]. The possible reason for increase in $\mathrm{NO}_{\mathrm{x}}$ emission is due to drop of engine power when fuelled with biodiesel ${ }^{[3]}$. There are many techniques followed to reduce $\mathrm{NO}_{\mathrm{x}}$ emissions when fuelled with biodiesel. The concept of using water based nanofluids to reduce $\mathrm{NO}_{\mathrm{x}}$ emission in compression ignition engines is an active area of research. Addition of water based nanoparticles in liquid fuels acts as a catalyst to promote the combustion and result in complete burning of fuels. ${ }^{[4]}$. Studies have shown that by adding water based nanofluid to biodiesel results in reduction in heat flux, thermal loading and metal temperature of combustion chamber components. Water based nanofluids alters the chemical composition of fuel which has encouraging impact on emission characteristics ${ }^{[5]}$. Nanosized energetic metals have enviable combustion characteristics such as high heat of combustion and fast energy release rates. Further, nanosized particles can be dispersed into high-temperature zones for direct oxidation reaction, rapid energy release, and enhanced propulsive performance with increased density impulse ${ }^{[6]}$. Many studies have been conducted to explore the impact of adding nanoparticles to fluid properties. Results revealed an enhancement in thermal conductivity, mass diffusivity and radiative heat transfer of fuel with addition of nanofluid ${ }^{[7]}$.

Nanoparticles with a high surface area to volume ratio increase the contact among fuel and oxidizer and reduce various emissions ${ }^{[8]}$. Nanoparticles affect the time scale of chemical reactions and result in reduced delay period and emissions ${ }^{[9]}$. Moreover, it has been experimentally found that by adding nanoparticles to the fuel increases the ignition probability of the mixture consequently reducing emissions ${ }^{[10]}$. This present work employs rice bran oil methyl ester as biodiesel. The most important reason for choosing Rice bran oil as a fuel is based on the selection of low-cost feed stock with high value added by- products. In addition, the chemical properties of rice bran are closer to that of petroleum diesel. The properties of transesterifed rice bran methyl ester fall well within the acceptable limit of ASTM standards. Rice bran is obtained as a by-product during polishing of rice from its kernel. Rice bran is dried to remove the water present in it. It is then fed to oil extractor which extracts oil by crushing. The oil obtained is classified as defatted and crude rice bran oil. Defatted rice bran oil with $16-20 \%$ of protein content is used for edible purpose. Crude rice bran oil with $23-24 \%$ free fatty acid is used as the main source of biodiesel production process. Crude rice bran oil is converted into its rice bran methyl ester by conventional transesterification process. Many studies have proved that the rice bran methyl ester when blended with diesel or used directly in engine has resulted in reduction in $\mathrm{CO}, \mathrm{HC}$ and smoke emissions. Gagendeep singh ${ }^{[11]}$ used rice bran oil and ethanol blend in a single cylinder direct injection diesel engine. He found reduction in $\mathrm{CO}, \mathrm{HC}$ and smoke emissions citing excess amount of oxygen present in rice bran oil as the cause. Narshima and Rajesh ${ }^{[12]}$ studied the emission characteristics of rice bran oil in single cylinder diesel engine. He too found reduction $\mathrm{CO}$ and $\mathrm{HC}$ with increase in $\mathrm{NO}_{\mathrm{x}}$ emissions indicating the availability of excess oxygen present in the fuel as the reason. Senthil kumar and Manimaran ${ }^{[13]}$ used rice bran oil as a biodiesel in diesel engine and found significant reduction in $\mathrm{CO}, \mathrm{HC}, \mathrm{NO}_{\mathrm{x}}$ and Smoke emissions owing to higher oxygen content and improved combustion. In recent times, adding nanoparticles to liquid fuel is subjected to a lot of investigation. Arul Mozhi Selvan ${ }^{[6]}$ studied the impact of cerium oxide nano particles of size $32 \mathrm{~nm}$ with a dosing level of $25 \mathrm{ppm}$ using diesterol in diesel engine. They found a significant reduction in $\mathrm{NO}_{\mathrm{X}}$ emissions. Shafii ${ }^{[9]}$ investigated the effect of water based ferrofluid with a size of $10 \mathrm{~nm}$ and a concentration of $0 \%, 0.4 \%$, and $0.8 \%$ by volume in diesel fuel to views its effects on performance and emissions characteristics. It was found that the magnetic particles improves the combustion characteristics and reduce $\mathrm{NO}_{\mathrm{x}}$ emissions. Kao ${ }^{[14]}$ analyzed the effect of aqueous aluminum nanofluid in single cylinder diesel engine fuelled with diesel. By adding 40-60 nm of aluminum nanofluid to diesel, $4.1 \%$ of smoke emissions and $6.2 \%$ of $\mathrm{NO}_{\mathrm{x}}$ emissions were found. This was attributed to increase in chaotic movements and reducing in settling velocity of the particles which aids combustions. However, the impact on addition of ferrofluid to rice bran oil methyl ester has never been experimented.

The present experimental study is aimed to examine the effect of ferrofluid on the various properties of rice bran methyl ester and also its influence on emissions characteristics. Experiments were conducted with RBOME and RBOMEF and are compared with petroleum diesel. RBOMEF was prepared comprising $98.7 \%$ biodiesel (Rice bran oil methyl ester), 1\% magnetite based ferrofluid and $0.3 \%$ surfactant by volume was used in a CI engine. The experimental analysis revealed a decrease in $\mathrm{HC}, \mathrm{CO}$ and $\mathrm{NO}_{\mathrm{x}}$ emissions of $10.8 \%, 9.1 \%$ and $8.49 \%$ respectively.

\section{EXPERIMENTAL MATERIAL \& METHODS}

\subsection{Materials and Reagents}

\subsubsection{RICE BRAN OIL}

Rice bran oil is extracted from the hard outer brown layer of rice after chaff (rice husk). Rice bran is the by-product of rice milling that contains $15-23 \%$ lipids which cannot be used for edible purposes and hence it is could be used as potential alternative fuel. Usage of low-priced, non-edible feedstock could possibly reduce the cost involved in production process. The alcohol used in this work is methanol with $99.5 \%$ purity. Potassium Hydroxide (98.5\% purity) is used as catalyst for transesterification process.

\subsubsection{FERROFLUID}

The ferrofluid used in this study is water-based. The synthesis involved the reaction between Iron $\mathrm{II}\left(\mathrm{FeCl}_{2}\right)$ and Iron $\mathrm{III}\left(\mathrm{FeCl}_{3}\right)$ ions in presence of aqueous ammonia solution to form magnetite $\left(\mathrm{Fe}_{3} \mathrm{O}_{4}\right)$ adapting the following Eq. 1 . 
$\mathrm{FeCl}_{2}+2 \mathrm{FeCl}_{3}+8 \mathrm{NH}_{3}+4 \mathrm{H}_{2} \mathrm{O} \rightarrow \mathrm{Fe}_{3} \mathrm{O}_{4}+8 \mathrm{NH}_{4} \mathrm{Cl} . \quad$ Eq.(1)

The cited procedure claims that those nano particle diameters are on the order of $10 \mathrm{~nm}{ }^{[11]}$. In addition, aqueous tri methyl ammonium hydroxide $\left(\left(\mathrm{CH}_{3}\right)_{3} \mathrm{NOH}\right)$ solution which was used as a surfactant can surround the magnetite particles with hydroxide anions and tetra methyl ammonium cations to create electrostatic inter particle repulsion in an aqueous environment ${ }^{[15]}$. The most significant reason for using ferrofluid is that the magnetic nano particles can be collected from exhaust using magnetic billets. Furthermore, it can be easily diluted to biodiesel and as a result it can collect the benefits of water- biodiesel emulsions.

2.2 Apparatus\& procedure

\subsubsection{PREPARATION OF BASE FUEL (RBOME):}

Ester was prepared by batch transesterification process in a $1000 \mathrm{ml}$ glass vessel reactor equipped with a magnetic stirrer, resistance heater \& ' $\mathrm{K}$ ' type thermocouple. Suitable arrangements were provided to control reaction temperature and stirring speed. Molar ratio of 5.9:1(methanol to Rice bran oil) and catalysts of $0.51 \%$ by weight of rice bran oil was used in transesterification procedure. $700 \mathrm{~g}$ sample of Rice bran oil in the reactor was heated till $60^{\circ} \mathrm{C}$ Measured mixture of solution containing catalysts mixed in methanol was added and mixed at a constant stirring speed of $300 \mathrm{rpm}$ for 60 minutes. This ensured uniform reactivity of solution by accelerating the reaction rate. The mixture was subsequently allowed to cool in the vessel yielding two distinct layers of ester and glycerol. Ester was then separated, washed with water and dried for further investigation. The ester thus obtained following conventional procedure is referred as RBOME. Table 1 . Show fatty acids compositions of rice bran oil using Gas-liquid chromatography technique.

Table 1. Fatty acids compositions of Rice bran oil.

\begin{tabular}{|c|c|c|}
\hline Fatty acids & Percentage & \multirow{4}{*}{$\begin{array}{c}\text { Gas-Liquid } \\
\text { Chromatography }\end{array}$} \\
\hline C14:0 Myristic acid & $0.8 \%$ & \\
\hline C16:0 Palmitic acid & $21.6 \%$ & \\
\hline C18:0 Stearic acid & $2.8 \%$ & \\
\hline C18:1 Oleic acid & $37.5 \%$ & \\
\hline C18:2 Linoleic acid & $35.4 \%$ & \\
\hline $\mathrm{C} 18: 3 \alpha$-Linolenic acid & $1.9 \%$ & \\
\hline
\end{tabular}

\subsubsection{PREPARATION OF MODIFIED BASE FUEL (RBOMEF):}

Copper strip corrosion test plays a very significant role in selection of dosage level limit of metal based additive to biodiesel. Fe $\mathrm{O}_{4}$ (Ferrofluid) has a property to corrode the engine parts if the limit exceeds $1 \%$ by volume as listed in ASTM limit of class 1b. The measure of ferrofluid and surfactant (aqueous tetra methyl ammonium hydroxide solution) in the base fuel (RBOME) is 1\% and $0.3 \%$ respectively by volume basis. The required quantity of the RBOME ferrofluid and surfactant is measured and mixed by ultrasonic agitator with constant agitation for better mixing and homogeneous suspension. Modified base fuel was kept in a glass vessel for examination at room temperature to observe the phase change characteristics. In stability test, due to the presence of surfactant ferrofluid showed long term stability and homogeneity with Rice bran oil methyl ester; hence the modified fuel can be used reliably for engine tests. Although the modified base fuel proved encouraging results on stability and homogeneity it was used straight away after preparation to study the accurate consequence of ferrofluid on emissions characteristics of Rice bran oil methyl ester. The fuel thus obtained following above procedure is referred as RBOMEF. Details for ferrofluid are listed in Table 2.

Table 2. Details for ferrofluid.

\begin{tabular}{|c|c|}
\hline Chemical name & $\mathrm{Fe}_{3} \mathrm{O}_{4}$ \\
\hline Average size of particle & $10 \mathrm{~nm}$ \\
\hline Appearance & Black \\
\hline State & Liquid \\
\hline
\end{tabular}

2.3 Comparisons on Fuel properties of RBOME and RBOMEF:

The effect of adding ferrofluid on fuel properties such as kinematic viscosity, flash point, water content, calorific value, cetane index and density is investigated. The comparison of fuel properties between RBOME, RBOMEF and Diesel is presented in Table 3. There is a significant change in all the properties with addition of ferrofluid. Kinematic viscosity is increased by $3.56 \%$ with addition of ferrofluid. This is due to increase in resistance between fluid layers which increases viscosity. Flash point is increased by $3^{\circ}$. Higher flash point is desirable for safer handling of fuel. RBOMEF is comparatively safe when compared to base fuel. Water content is increased by $0.02 \%$ with addition of ferrofluid. Since ferrofluid has considerable measure of water present in it, there is a marginal increase in water content. Other property such as cetane index, calorific value and density of RBOMEF is improved by $5.45 \%$, $2.60 \%$ and $2.97 \%$ respectively. This is due to positive effects of ferrofluid as cited by Shafii ${ }^{[9]}$.

Table 3. Properties of Diesel, RBOME and RBOMEF.

\begin{tabular}{|c|c|c|c|c|}
\hline Properties & RBOME & RBOMEF & Diesel & $\begin{array}{c}\text { ASTM } \\
\text { standards }\end{array}$ \\
\hline Kinematic Viscosity [cst] & 6.32 & 6.55 & 4.30 & $\begin{array}{c}\text { ASTM } \\
\text { D445 }\end{array}$ \\
\hline Flash point [ $\left.{ }^{\circ} \mathrm{C}\right]$ & 138 & 144 & 50 & $\begin{array}{c}\text { ASTM } \\
\text { D93 }\end{array}$ \\
\hline Water content [\%] & 0.13 & 0.15 & 0.00 & $\begin{array}{c}\text { ASTM } \\
\text { D2709 }\end{array}$ \\
\hline Density [gm/cc] & 0.882 & 0.910 & 0.820 & $\begin{array}{c}\text { ASTM } \\
\text { D4052 }\end{array}$ \\
\hline Calorific Value [kJ/kg] & 38123 & 39143 & 42957 & $\begin{array}{c}\text { ASTM } \\
\text { D240 }\end{array}$ \\
\hline Cetane Index & 52 & 55 & 46 & $\begin{array}{c}\text { ASTM } \\
\text { D976 }\end{array}$ \\
\hline
\end{tabular}

2.4 Engine test set-up \& procedure

Experimental analysis is carried out by means of four stroke, two cylinder, air cooled diesel engine. Table. 4 shows the specification of engine. An eddy current dynamometer is coupled with engine to vary the load on engine. Eddy current dynamometers use a varying magnetic field in a coil to generate eddy currents. Magnetic field induced creates a torque which opposes the engine shaft's direction of rotation which is referred as load. The load to the engine is varied by altering the load on dynamometer by switching on or off the load resistances. Bank of electrical resistances is used to supply to load to dynamometer and is measured by means of load cell attached with arm. Load power (Load power $=$ is calculated from measurement of voltage $\mathrm{V}$ and current intensity I applied. Figure 1 shows the layout of engine setup. Engine exhaust was linked to AVL444 di gas analyzer for monitoring the engine emissions. Details of gas analyzer and smoke meter are shown in Table 5. Experiment is initially conducted with diesel following RBOME and RBOMEF at different loads viz $0 \%$ to $100 \%$ insteps of $25 \%$. In order to fix the base line all the parameters necessary for evaluating the emissions were measured. Constant engine speed of $1500 \mathrm{rpm}$ was maintained at all loads and test fuels
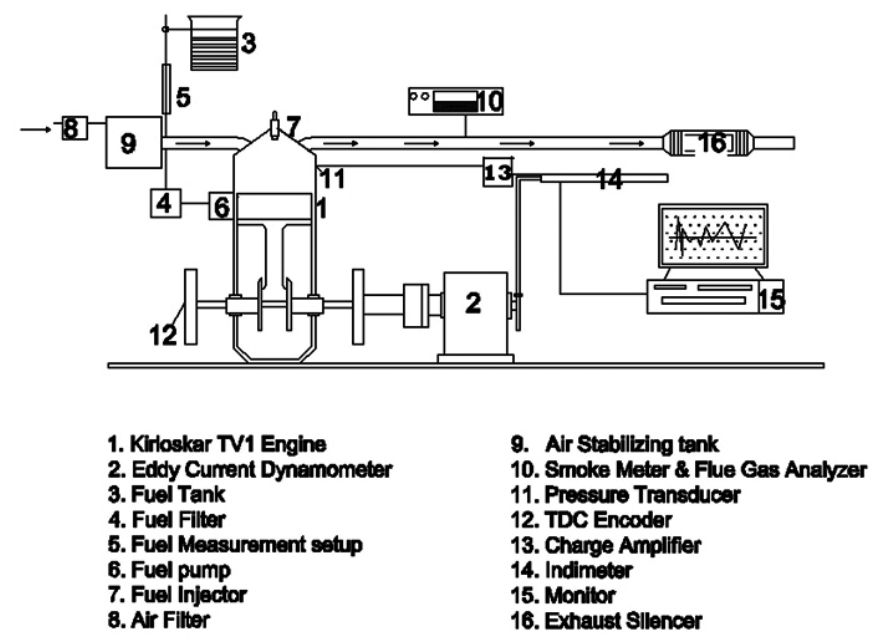

Fig. 1. Layout of engine and instrumentation set up. 
Table 4. Engine specifications.

\begin{tabular}{|c|c|}
\hline Make & Kirloskar \\
\hline Stroke & 4 \\
\hline Cylinder & Two \\
\hline Rated Power & $4.4 \mathrm{~kW}$ \\
\hline Rated speed & $1500 \mathrm{rpm}$ \\
\hline Bore dia(D) & $87.5 \mathrm{~mm}$ \\
\hline Stroke(L) & $110 \mathrm{~mm}$ \\
\hline Compression ratio & $17.5: 1$ \\
\hline Cooling & Air cooled \\
\hline Loading device & Eddy current dynamometer \\
\hline
\end{tabular}

Table 5. Gas analyzer and Smoke meter details

\begin{tabular}{|c|c|c|c|c|}
\hline Parameters & Model & Range & Accuracy & Uncertainty \\
\hline $\mathrm{CO}$ & \multirow{3}{*}{ AVL 444 di gas analyzer } & $0-10 \%$ Volume & 0.01 & $\pm 3 \%$ \\
\hline $\mathrm{HC}$ & & $0-20000$ & $\pm 10 \mathrm{ppm}$ & $\pm 2 \%$ \\
\hline NOx & & $0-5000 \mathrm{ppm}$ & $\pm 10 \mathrm{ppm}$ & $\pm 2.5 \%$ \\
\hline Smoke & AVL 437 Smoke meter & $0-100 \%$ opacity & $\pm 1 \%$ full of scale reading & $\pm 4 \%$ \\
\hline
\end{tabular}

\subsection{Error Analysis}

Equation 2 indicates the error analysis for $\mathrm{HC}$ emissions. Method proposed by J.P. Holman which is extensively accepted is followed to calculate error analysis for all emissions. According to his root-mean square method the uncertainty of the variable can be found by the following equation.

$$
\sigma_{\mathrm{HC}}=\left[\frac{\sum_{i=1}^{n}\left((H C)_{i}-(\overline{H C})\right)^{2}}{n-1}\right]^{\frac{1}{2}} \quad \text { Eq. (2) }
$$

The uncertainty in $\Delta$ (HC) in hydrocarbons is calculated by Eq.(3)

$$
\frac{\sigma_{H C}}{\sqrt{n}} \quad \text { Eq.(3) }
$$

Where $\mathrm{n} \quad=$ number of $\mathrm{HC}$ measurements,

$$
\begin{array}{ll}
\overline{\mathrm{HC}} & =\text { mean value of } \mathrm{HC} \text { measurements, } \\
\sigma_{\mathrm{HC}} & =\text { unbiased standard deviation for HC measurements. }
\end{array}
$$

By following the above equation, the error analysis of other emissions such as $\mathrm{CO}, \mathrm{NO}_{\mathrm{x}}$ and Smoke were analysed.

\section{RESULTS AND DISCUSSION}

To examine the consequence on adding ferrofluid the emissions such as Carbon monoxide (CO), unburned hydrocarbon (UHC), Oxides of Nitrogen $\left(\mathrm{NO}_{x}\right)$ and Smoke opacity is measured and examined. The measurements were analyzed with respect to emissions and the corresponding outcomes are detailed as follows.

\subsection{Carbon monoxide ( $\mathrm{CO}$ )}

Loss of chemical energy is an outcome of $\mathrm{CO}$ emissions. Variation in $\mathrm{CO}$ emissions with load is shown in "Fig. 2". It is evident from the figure that CO emissions from RBOME and RBOMEF are lower than diesel. $\mathrm{CO}$ emissions from RBOME and RBOMEF were $10.1 \%$ and $12.2 \%$ lower when compared to diesel. Since the oxygen content in both the fuels are higher than diesel oxidation reaction is enhanced and thereby result in lesser $\mathrm{CO}$ emissions. $\mathrm{CO}$ emission is found to increases with increase in load for all fuels. With rise in load quantity of fuel injected is more causing lesser oxidation of $\mathrm{CO}$ and result in higher $\mathrm{CO}$ emissions. The average $\mathrm{CO}$ emissions from RBOMEF at all loads is $6.34 \%$ lesser than RBOME. This is due to effect of ferrofluid which undergoes catalytic oxidation reaction by providing surplus oxygen. Similar results were reported by Arul Mozhi Selvan ${ }^{\left[{ }^{[6]}\right.}$ by adding nanoparticles to liquid fuel. In addition nanofluid enhances the physical properties of fuel and result in lesser CO emissions. Further, ferrofluid undergoes catalytic oxidation reaction and improves the mixing rate of fuel with air. This result is in agreement with work done by Sadhik Basha and Lenin ${ }^{[5 \& 7]}$.

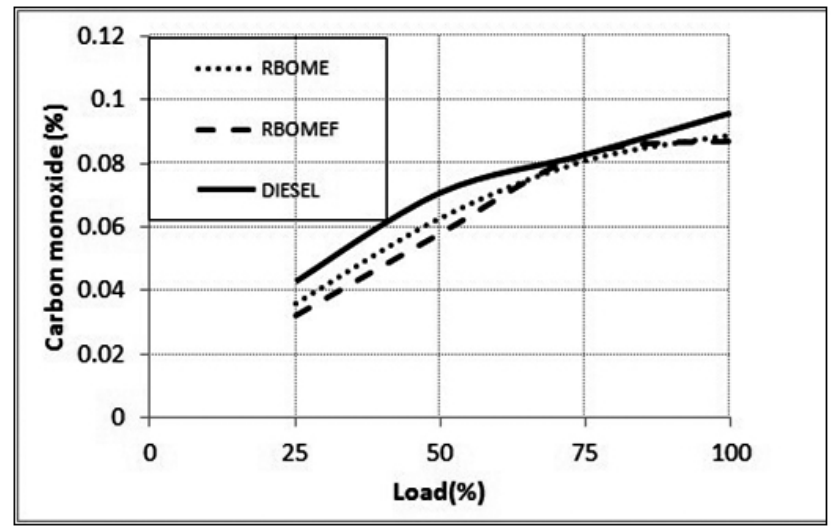

Fig. 2. Change in $\mathrm{CO}$ emission with loads.

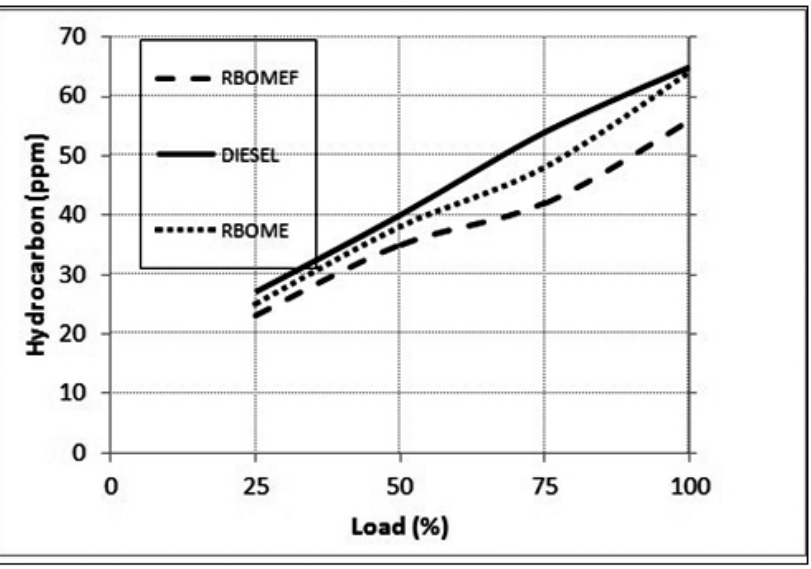

Fig. 3. Change in $\mathrm{HC}$ emissions with loads. 


\subsection{Unburned hydrocarbon (UHC)}

Variation in HC emissions with load is shown in "Fig.3". The average HC emission from diesel at all loads is found to be $43.5 \mathrm{ppm}$ while that from RBOME and RBOMEF were $42.7 \mathrm{ppm}$ and $36.0 \mathrm{ppm}$ respectively. $\mathrm{HC}$ emissions from RBOME and RBOMEF were $10.6 \%$ and $17.58 \%$ lower than that of diesel. This is due to higher oxygen content in both methyl ester promoting better combustion and resulting in lesser $\mathrm{HC}$ emission. The average $\mathrm{HC}$ emissions from RBOMEF at all loads is $9.1 \%$ lesser than RBOME. Nanofluid as an oxidation catalysts oxidise $\mathrm{HC}$ and lowers the carbon combustion activation temperature. Furthermore, nanoparticles significantly increase the ignition probability of the mixture and reduce $\mathrm{HC}$ emissions. Similar reduction in $\mathrm{HC}$ was cited on experimental work by Kannan and Patel ${ }^{[8 \& 16]}$.

\subsection{Oxides of Nitrogen ( $\mathrm{NO}$ )}

Figure 4 shows variation in $\mathrm{NO}_{x}$ emissions with load. $\mathrm{NO}_{x}$ emissions from RBOME and RBOMEF were $13.5 \%$ and $16.74 \%$ higher than that of diesel. Formation of $\mathrm{NO}_{x}$ depends on oxygen concentration in the fuel. Since both RBOME and RBOMEF has higher oxygen content comparing diesel, Increase in $\mathrm{NO}$ is obvious. $\mathrm{NO}$ emission for RBOME is $8.49 \%$ higher than RBOMEF. Ferrofluid exhibits a high catalytic activity leading to enhancement in combustion and reduction in the $\mathrm{NO}_{\mathrm{x}}$ emissions. Additionally, water in the nanofluid enhances the thermal conductivity and latent heat evaporation. This leads to reducing in $\mathrm{NO}_{\mathrm{x}}$ emissions. This result is in agreement with similar trial done by Patel ${ }^{[16]}$.

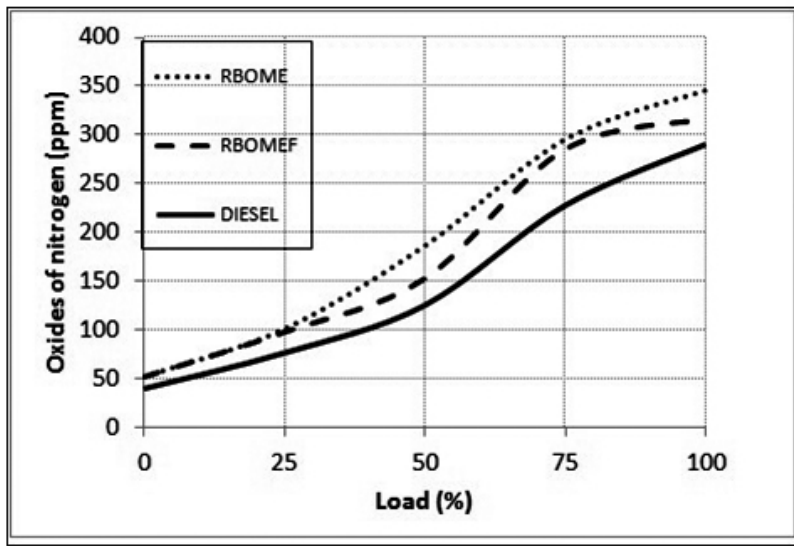

Fig. 4. Change in NOx emission with loads

\subsection{Smoke opacity}

Figure 5 shows exhaust smoke emission of RBOME, RBOMEF and Diese for various loads. Smoke emission for RBOME and RBOMEF is less than diesel. This is due to higher oxygen availability in methyl esters prompting combustion rate. Smoke emission from RBOMEF is $3.85 \%$ lesser than RBOME. Addition of nanofluid to RBOME has resulted in better evaporation and improved ignition characteristics. The other reason is due to presence of surplus oxygen which acts as oxidation catalysts. This is in agreement with similar work done by Shafii and Patel ${ }^{[9 \& 16]}$.

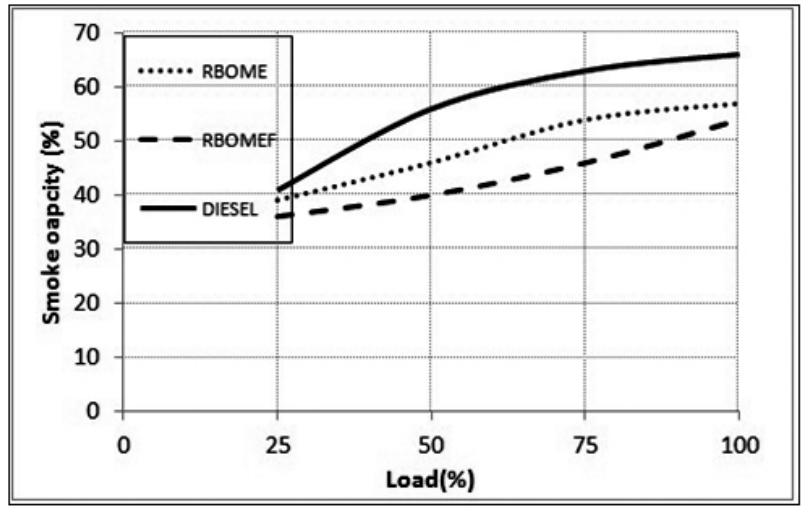

Fig. 5. Change in smoke emission with loads

\section{CONCLUSIONS}

Emission analysis on the influence of magnetite nanofluid on rice bran oil methyl ester is carried out in two cylinder CI engine. Addition of magnetite in nano form, to the biodiesel along with surfactant controls the eco-friendliness of biodiesel. The following are the main conclusions drawn from this work,

(1) $\mathrm{CO}$ emission reduces significantly by $6.34 \%$ by adding ferrofluic to methyl ester.

(2) $\mathrm{HC}$ emission reduces by $6.34 \%$ with addition of ferrofluid.

(3) $\mathrm{NO}_{x}$ drops by $8.49 \%$ by adding ferrofluid.

(4) Smoke reduces by $3.85 \%$ by adding ferrofluid to rice bran methyl ester.

Hence addition of nanofluid to rice bran methyl ester results in superior combustion and thereby reducing emissions persisting in conventional biodiesel.

\section{REFERENCES}

1.- MM. Roy, W. Wang, and J. Bujold, Biodiesel production and comparison of emissions of a DI diesel engine fueled by biodiesel-diesel and canola oil-diesel blends at high idling operations, Applied Energy, 106, 198-208, (2013).

2.- S MA. Rahman, HH. Masjuki, MA. Kalam, MJ. Abedin, A. Sanjid, and S. Imtenan, Effect of idling on fuel consumption and emissions of a diesel engine fueled by Jatropha biodiesel blends, Journal of Cleaner Production, 69, 208-215, (2014).

3.- S. Imtenan, HH. Masjuki, M. Varman, IM. Rizwanul Fattah, H. Sajjad, and MI. Arbab, Effect of n-butanol and diethyl ether as oxygenated additives on combustion-emission-performance characteristics of a multiple cylinder diesel engine fuelled with diesel-jatropha biodiesel blend, Energy Conversion and Management, 94, 84-94, (2015).

4.- K. Rajan, M. Prabhahar, and KR. Senthilkumar, Experimental studies on the performance, emission and combustion characteristics of a biodieselfuelled (Pongamia methyl ester) diesel engine with diethyl ether as an oxygenated fuel additive, International Journal of Ambient Energy, 1-7, (2014).

5.- J. Sadhik Basha and RB. Anand, Role of nanoadditive blended biodiesel emulsion fuel on the working characteristics of a diesel engine, Journal of Renewable and Sustainable Energy, 3, 2, 023106, (2011).

6.- V. Arul Mozhi Selvan, RB. Anand, and M. Udayakumar, Effect of Cerium Oxide Nanoparticles and Carbon Nanotubes as fuel-borne additives in Diesterol blends on the performance, combustion and emission characteristics of a variable compression ratio engine, Fuel, 130, 160 167, (2014)

7.- MA. Lenin, MR. Swaminathan, and G. Kumaresan, Performance and emission characteristics of a DI diesel engine with a nanofuel additive, Fuel, 109, 362-365, (2013).

8.- GR. Kannan, R. Karvembu, and R. Anand, Effect of metal based additive on performance emission and combustion characteristics of diesel engine fuelled with biodiesel, Applied Energy, 88,11, 3694-3703, (2011).

9.- MB. Shafii, F. Daneshvar, N. Jahani, and K. Mobini, Effect of Ferrofluid on the Performance and Emission Patterns of a Four-Stroke Diesel Engine, Advances in Mechanical Engineering, 3, 529049-529049, (2011).

10.- H. Kim and B. Choi, The effect of biodiesel and bioethanol blended diesel fuel on nanoparticles and exhaust emissions from CRDI diesel engine, Renewable Energy, 35, 1, 157-163, (2010).

11.- Gagendeep singh, Rupinder singh, and Gurpreet Singh Batth, Utilization of Rice Bran Oil and Ethanol blend in a Single Cylinder DI Diesel Engine, International Journal of Emerging Science and Engineering, 1, 10, 25-28, (2013)

12.- CH. Narshima, and M.Rajesh, Performance and emissions characteristics of diesel engine fuelled with rice bran oil, International Journal of Engineering Trends and Technology, 4, 10, 4574-4578, (2013)

13.- R. Senthil kumar and R. Manimaran, Evaluation of a diesel engine using rice bran oil as a bio-diesel. International Journal of Science Engineering and Technology Research, 3, 6, 1779-1789, (2014)

14.- MR. Mitchell, RE. Link, MJ. Kao, CC.Ting, BF. Lin, and TT. Tsung, Aqueous Aluminum Nanofluid Combustion in Diesel Fuel. Journal of Testing and Evaluation, 36, 2, 100579, (2008)

15.- P. Berger, NB. Adelman, KJ. Beckman, DJ. Campbell, AB. Ellis, and GC. Lisensky, Preparation and Properties of an Aqueous Ferrofluid, Journal of Chemical Education, 76, 7, 943, (1999). 
16.- PM. Patel, Effect of magnetic field on performance and emission of single cylinder four stroke diesel engine, IOSRJEN, 4, 5, 28-34, (2014)

Nomenclature

\begin{tabular}{|l|l|}
\hline$C I$ & Combustion ignition \\
\hline$R B O M E$ & Rice bran oil methyl ester \\
\hline$R B O M E F$ & Rice bran oil methyl ester with addition of Ferrofluid \\
\hline$C O$ & Carbon monoxide \\
\hline$U H C$ & Unburned Hydrocarbon \\
\hline$N O_{x}$ & Nitrogen oxide \\
\hline
\end{tabular}

